\author{
Michał A. Michalski \\ Adam Mickiewicz University in Poznań \\ Faculty of Social Sciences \\ e-mail: mmichal@amu.edu.pl
}

\title{
Starzenie się społeczeństwa w kontekście dominujących założeń współczesnej ekonomii i kultury
}

\section{Aging of the Society in the Context of Dominant Assumptions of Contemporary Economics and Culture}

Current demographic trends indicate that the process of aging is more and more advanced in Western societies. While available literature addressing this issue most often concentrates on developing effective tools for socio-economic policy, this paper aims at exploring dominating assumptions of economics and culture to find how they may influence the demographic process that was mentioned. The purpose of the analysis undertaken here is to verify the thesis which claims that basic anthropological assumptions present in neoclassical economics and modern culture somehow ignore or underestimate such essential aspects of human life as old age and helplessness or weakness connected to it.

The conclusions of the paper indicate that there is the need for intergenerational balance within society which e.g. facilitates socio-economic development. Some of the most important factors influencing this may or may not be present within economic theory and culture it is based on. It means that without the adequate vision of human being and phases of human life the process of building a sane and vibrant society where everyone has his or her place is hardly possible.

Keywords: ageing, pensioners, sociodemographic, economic thought

JEL Classification: J11, J14 


\section{Wprowadzenie}

Celem niniejszego artykułu jest spojrzenie na to, jaką rolę odgrywa teoria ekonomiczna - a w szerszej perspektywie kultura - w postrzeganiu realnych zjawisk społecznych oraz podejmowaniu decyzji ich dotyczących. Uwaga zostanie skoncentrowana na znaczeniu teoretycznych założeń dotyczących osoby ludzkiej - w szczególności kwestii starości - dla funkcjonowania ładu społeczno-gospodarczego. Podjęcie tak ukierunkowanej analizy wydaje się o tyle interesujące i ważne, że starzenie się społeczeństw staje się zagadnieniem coraz bardziej aktualnym i dlatego zasługuje na możliwie najszerszą refleksję.

Chodzi więc o to, by zastanowić się, w jakim stopniu rozstrzygnięcia w obrębie dominującej teorii ekonomicznej - traktowanej tu jako jeden $\mathrm{z}$ elementów kultury - wspierają adekwatne rozumienie zachodzących procesów oraz wpływają na umiejętne rozwiązywanie problemów, które wraz z nimi się pojawiają.

W dostępnej literaturze związki pomiędzy starzeniem się społeczeństwa a polityką społeczno-gospodarczą stanowią przedmiot refleksji badaczy przede wszystkim z takich dyscyplin, jak demografia, ekonomia czy socjologia. Dlatego też w głównej mierze perspektywa, jaką przyjmuję, odwoływać się będzie do nauk o kulturze, które dostarczają szerszej ramy poznawczej do refleksji nad obecnością kategorii starości i jej statusem w teorii ekonomicznej. Przyglądając się rosnącej liczbie badań i analiz poświęconych starzeniu się społeczeństw, należy zauważyć, że, koncentrując się na zaproponowaniu rozwiązań z poziomu polityki społeczno-gospodarczej, rzadziej podejmują one kwestię adekwatności przyjmowanej antropologii, a więc sposobu widzenia człowieka jako podmiotu życia społecznego. Ten niedostatek w jakimś stopniu stara się uzupełnić podjęta tu refleksja.

Dlatego też stawiam tezę, że odpowiednie zrozumienie i ustosunkowanie się do procesu starzenia się społeczeństwa, a także właściwe pokierowanie nim, wymaga $\mathrm{z}$ jednej strony poszerzenia, a nawet wyjścia poza perspektywę ekonomii neoklasycznej i przyjętego przez nią modelu homo oeconomicus, a z drugiej krytycznego przeanalizowania rozstrzygnięć kulturowych, które sprzyjają pojawianiu się i utrwalaniu niekorzystnej z punktu widzenia rozwoju społeczno-gospodarczego struktury wiekowej.

\section{Starość jako naturalny etap życia ludzkiego i komponent ladu społecznego}

Podejmując temat związany ze starością, należy na początku ustalić sposób rozumienia tego pojęcia, które odnosi się do uniwersalnego doświadczenia ludzkiego.

Warto zauważyć, że starość sama w sobie nie jest problemem, gdyż jest obiektywnym procesem, który wpisany jest w porządek życia ludzkiego. Należy natomiast zauważyć, że związane są z nią określone trudności - zarówno w wymiarze jednostkowym, jak i społecznym. Starzeją się więc nie tylko konkretne 
osoby, ale mówi się także o starzeniu się populacji ${ }^{1}$. To z kolei przekłada się na to, że - szczególnie w ostatnich latach - starość staje się nie tylko ważnym wyzwaniem dla polityki społeczno-gospodarczej, ale także, co ma z tym związek, popularnym przedmiotem badań i źródłem problematyki badawczej ${ }^{2}$.

Powracając do kwestii definicji starości, napotykamy niełatwe zadanie, o czym świadczy literatura $\mathrm{z}$ analizowanego przedmiotu. Jak pisze Łukasz Jurek, jak dotąd nie ma jednomyślności w kwestii powszechnie uznanego progu starości. Zauważa on natomiast, że większość badaczy przyjmuje, iż właściwym kryterium uznania kogoś za osobę starą jest osiągnięcie wieku na poziomie pomiędzy sześćdziesiątym a sześćdziesiątym piątym rokiem życia ${ }^{3}$.

$\mathrm{U}$ innego autora wyróżnione zostały z kolei trzy podejścia do definiowania starości. Pierwsze z nich, określane jako subiektywne, odwołuje się do tego, w jaki sposób dana osoba sama ocenia swą aktywność na rynku pracy oraz sytuację pod względem stanu zdrowia. Drugie podejście, określane mianem funkcjonalnego, wykorzystuje obiektywne informacje, takie jak status pod względem zatrudnienia czy otrzymywania określonych świadczeń lub kondycji psychicznej. Trzecia propozycja zaliczenia kogoś w poczet osób starych bazuje na kryterium wieku, który uprawnia do otrzymywania świadczeń emerytalnych lub korzyści związanych z przeżyciem określonej liczby lat ${ }^{4}$. Uzupełniając tę listę, warto zastanowić się, czy nie zaproponować rozumienia starości jako tego etapu życia, w którym dobitnie i znacznie wyraźniej niż w wieku produkcyjnym ujawnia się nasza słabość i niesamodzielność. W przypadku takiego definiowania unikamy chociażby ograniczeń czysto formalnej czy liczbowej natury z jednej strony, a z drugiej silnie zsubiektywizowanego punktu widzenia konkretnej osoby ${ }^{5}$.

W obliczu ukazanych stanowisk w tym opracowaniu przyjęty zostanie ten ostatni sposób rozumienia pojęcia „starość”, oferujący możliwie najbardziej obiektywną perspektywę wyróżniania interesującej nas kategorii. Zdaję sobie zarazem sprawę, że nie jest on doskonały, i że inne podejścia mogą być zasadne i przydatne ${ }^{6}$.

Jeśli chodzi o przyjęte rozumienie starości, to należy doprecyzować kilka kwestii. Po pierwsze, starość uznana jest tu za naturalną fazę ludzkiego życia, co oznacza, że jest ona nieodłączną konsekwencją (choć nie zawsze urzeczywistnioną w sytuacji, gdy śmierć następuje wcześniej) i z tej racji nieuchronnym etapem egzystencji człowieka. Jako taka więc powinna być ujmowana jako istotny ele-

\footnotetext{
${ }^{1}$ Cf. Ł. Jurek, Ekonomia starzejącego się społeczeństwa, Difin, Warszawa 2012, s. 17.

${ }^{2}$ Cf. S. Golinowska, Społeczno-ekonomiczne konsekwencje starzenia się ludności [w:] Konsekwencje ekonomiczne i społeczne starzenia się społeczeństwa, red. J. Kleer, Komitet Prognoz „Polska 2000 plus" przy Prezydium PAN, Warszawa 2008, s. 27.

${ }^{3}$ Cf. Ł. Jurek, op. cit., s. 19.

${ }^{4}$ Cf. A. Zaidi, Well-being of Older People in Ageing Societies, Ashgate, Aldershot 2008, s. 28.

${ }^{5} \mathrm{~W}$ jakiś sposób takie rozumienie starości jest odzwierciedlone przez system świadczeń społecznych, w którym z jednej strony funkcjonują emerytury przyznawane według kryteriów wieku czy liczby przepracowanych lat (które można rozumieć umownie jako wyczerpanie zasobów energii niezbędnej do pracy zawodowej), a z drugiej renty, przyznawane w szczególnych okolicznościach bez względu na wiek osobom, które $\mathrm{z}$ różnych względów znalazły się $\mathrm{z}$ jakichś powodów właśnie $\mathrm{w}$ sytuacji słabości i niesamodzielności.

${ }^{6}$ Interesująco na temat trudności z definiowaniem starości pisze Jan Szczepański (Sprawy ludzkie, Czytelnik, Warszawa 1980, s. 228-240).
} 
ment związany z funkcjonowaniem ładu społeczno-gospodarczego. Po drugie, starość - podobnie jak dzieciństwo - ukazuje bardzo dobitnie tę zasadniczą cechę ludzkich relacji, której nie jest w stanie właściwie uchwycić myślenie wyłącznie kategoriami ekonomicznymi. Pokazuje ona mianowicie wyraźnie, że w społeczeństwie zawsze istnieć będzie przestrzeń relacji niesymetrycznych - w których brak jest równości, jeśli chodzi o wkład czy potencjał ich uczestników - będących zasadniczo czymś innym niż symetryczne relacje łączące partnerów rynkowych ${ }^{7}$. O swoistej przewadze liczebnej tych pierwszych w życiu ludzkim pisze Chantal Delsol, która stwierdza:

Unikanie związu nierówności między darczyńca a obdarowanym niszczy relację. (...) Równość jest uszanowana, ale relacja zostaje zerwana. Tymczasem w porzadku ludzkich więzi tylko prawdziwa przyjaźń zakłada równość. Wszystkie pozostałe relacje sa nierówne, inaczej mówiąc, zakładają dar czasem bez rewanż ${ }^{8}$.

To zaś oznacza, że ekonomia jako dyscyplina specjalizująca się w interakcjach o symetrycznym charakterze nie jest w stanie wyjaśnić specyfiki szerokiej gamy zjawisk i zachowań niekomercyjnych ${ }^{9}$. Celowo nie zostało tu użyte sformułowanie ,pozagospodarcze”, by nie kojarzyć z gospodarką wyłącznie tych działań, które dotyczą wymiany towarowo-pieniężnej podejmowanej na zasadach rynkowych. Dzięki temu nie znika z pola widzenia obszar związany z prowadzeniem chociażby gospodarstwa domowego, w którym przecież dokonuje się ogromna liczba aktów natury gospodarczej, bo nastawionych na zaspokojenie konkretnych ludzkich potrzeb za pośrednictwem dostępnych środków i zasobów materialnych.

Wydaje się więc, że poprzez zwrócenie uwagi na kategorię starości - i tak wyraźnie związane z nią doświadczenie ludzkiej bezradności - pojawia się szansa, by przywrócić realne kształty podmiotowi procesów społeczno-gospodarczych, który choć „oficjalnie” jest nazywany człowiekiem, to wydaje się, że z czasem utracił konkretne ludzkie kształty i atrybuty. Tej kwestii spróbujemy się przyjrzeć.

\section{Ekonomia a starość - kim jest „bohater” neoklasycznej teorii ekonomicznej i jaka jest jego logika?}

W tym miejscu chcemy przyjrzeć się podmiotowi działań gospodarczych, i to takiemu, jakim widzi go ekonomia. Chodzi przede wszystkim o wykazanie, że w przyjmowanym najczęściej $\mathrm{w}$ naukach ekonomicznych ${ }^{10}$ modelu człowieka

\footnotetext{
${ }^{7}$ Cf. J. Roback Morse, Love \& Economics: Why the Laissez-Faire Family Doesn't Work, Spence Publishing Company, Dallas 2001, s. 25.

${ }^{8}$ Ch. Delsol, Esej o człowieku późnej nowoczesności, tłum. M. Kowalska, Znak, Kraków 2003, s. 154.

${ }^{9}$ Należy tu podkreślić wkład m.in. Gary’ego S. Beckera, który poprzez przykładanie narzędzi ekonomicznych do zachowań niekojarzonych z tą dyscypliną wiedzy w jakimś stopniu przyczynił się do zwrócenia uwagi na kwestie wcześniej niedostatecznie poważane, takie jak np. znaczenie rodziny dla funkcjonowania gospodarki.

${ }^{10}$ Chodzi tu przede wszystkim o ekonomię neoklasyczną, która od mniej więcej lat siedemdziesiątych XX wieku zdominowała teorię ekonomiczną i wciąż wydaje się stanowić główny nurt. Cf. W. Stan-
} 
brakuje zasadniczych cech charakterystycznych, które wiążą się z kategorią starości. Warto więc przyjrzeć się genezie czlowieka ekonomicznego, który - choć w ostatnich latach poddawany był, i nadal jest, różnorakiej krytyce - wydaje się wciąż ważnym punktem odniesienia dla myślenia o zagadnieniach ekonomicznych ${ }^{11}$. Gdy chodzi więc o początki koncepcji homo oeconomicusa, to, jak pisze Janusz R. Sobczyk:

najbliżej kolebki jego narodzin stali, odpowiedzialni za tę przewrotna żonglerke pojęciowa: A. Smith (ekonomia klasyczna), J. Bentham (utylitaryzm) J. Mill iJ.S. Mill; a za ich plecami cała tradycja filozofii angielskiej: empiryzm (F. Bacona), mechanistyczna ontologia (I. Newtona), sensualistyczna epistemologia (J. Locke'a), asocjacyjna psychologia (D. Hume'a) oraz naturalistyczna etyka egoizmu i hedonizmu (T. Hobbes'a). W ten sposób oto nowo zaistniaty twór, będacy intelektualnym produktem typowej mentalności angielskiej-jeszcze pod postacia bezimiennej idei, czy, jak kto woli, milczacego zatożenia, staje się osnowa mieszczańskich wyobrażeń o naturze człowieka, rynku i ekonomii ${ }^{12}$.

Powyższy opis wydaje się o tyle istotny, że ukazuje, jakie koncepcje filozoficzne, w tym etyczne, oraz antropologiczne da się odnaleźć w „osobowości” homo oeconomicusa. Dodatkowo dookreśla go Frank Knight, który stwierdza, że

czlowiek ekonomiczny nie jest ,,istota społeczna”, ekonomiczny indywidualizm wyklucza społeczeństwo we właściwym ludzkim sensie tego słowa. Relacje ekonomiczne sa przezeń ujęte jako bezosobowe. Organizacja społeczna, tak, jak ja ujmuje teoria ekonomiczna, to pewna liczba Robinsonów oddziałujacych ze soba wyłacznie poprzez rynek ${ }^{13}$.

W istocie jednak - jak to już zostało zauważone - doświadczenie słabości, bezbronności i bezradności stanowi nieodłączną (choć w różnym wymiarze) cechę ludzkiego życia i nie jest zarezerwowane wyłącznie dla okresu dzieciństwa i starości. Oznacza to więc, że asymetryczność z tym się wiążącą należy traktować jako zasadniczy rys ludzkiej kondycji. Nie oznacza to jednak, że jedynie relacje, w których brak jest symetrii, należy uznać wyłącznie za prawdziwie ludzkie.

By to właściwie ukazać, warto przedstawić powyższy problem w postaci dwóch logik: daru i kontraktu. Otóż pierwsza z nich to ta, która zdaniem Chantal Delsol na swój sposób warunkuje istnienie społeczeństwa. Autorka ta zauważa, że

kiewicz, Historia myśli ekonomicznej, Polskie Wydawnictwo Ekonomiczne, Warszawa 1998, s. 390-391, 416-423.

${ }^{11}$ Oczywiście należy wspomnieć o koncepcji „człowieka socjologicznego”, która stanowi próbę, znacznej mierze udaną, poszerzenia i rozwinięcia sposobu myślenia o człowieku. O ile jednak zdobyła ona sporą popularność w socjologii, to wydaje się, że w naukach ekonomicznych wciąż sposób widzenia osoby ludzkiej zdominowany jest przez model „człowieka ekonomicznego”. Cf. W. Morawski, Socjologia ekonomiczna. Problemy. Teoria. Empiria, Wydawnictwo Naukowe PWN, Warszawa 2001, s. 33.

${ }^{12}$ J.R. Sobczyk, Historia naturalna homo oeconomicus - od narodzin po cywilizacyjny kryzys wspótczesności [w:] Kultura a rynek, red. S. Partycki, Wydawnictwo KUL, Lublin 2008, s. 140.

${ }^{13}$ F. Knight, The Ethics of Competition, New York 1951, s. 282, cyt. za: A. Chmielecki, Rzeczy $i$ wartości. Humanistyczne podstawy edukacji ekonomicznej, Wydawnictwo Naukowe PWN, Warszawa 1999 , s. 260. 
każda ludzka relacja zaczyna się od braku i od zgody na to, że ktoś go wypetni. I nie chodzi o to, by raz na zawsze naprawić sytuację nienormalna lub niesprawiedliwa, co znaczyloby, że dążymy do samowystarczalności uznawanej za stan normalny. Podstawowym warunkiem istnienia społeczeństwa jest zgoda na konstytutywna niesamowystarczalność. Tylko wtedy mogę nawiazać relacje, kiedy uznaję swój własny brak i uważam go nie za okolicznościowy wyjątek, nie za niesprawiedliwość, która trzeba naprawić, ale za moja cechę substancjalną. Tylko poczucie skończoności rodzi wspólny świat, a zarazem nadaje mu sens ${ }^{14}$.

Powyższe słowa mogą się wydawać bardzo poważne, ale być może w nich da się odnaleźć wyjaśnienie tego, co na różne sposoby bywa określane mianem erozji więzi społecznych ${ }^{15}$, której może sprzyjać upowszechnianie się relacji o charakterze symetrycznym i związanej z nimi logiki kontraktu.

Gdy chodzi o zestawienie tej ostatniej oraz tej wcześniej przywołanej, to wydaje się, że współcześnie dominuje pogląd, iż to logika kontraktu jest bardziej skuteczna i przydatna $\mathrm{w}$ codziennym życiu. W takim sposobie myślenia ujawnia się jednak przekonanie o swoistej opozycyjności obu tych logik. W rzeczywistości są one raczej komplementarne, a nie alternatywne względem siebie, podobnie jak np. sfera życia rodzinnego nie powinna być traktowana jako przeciwna sferze wymiany rynkowej. Dobrze rozumie to Luigino Bruni, który pisze, że (...) kontrakty (wymiana nastawiona na wtasny interes) $i$ wzajemne akty daru sa z pewnościa dwoma różnymi formami wzajemności, ale obie sa formami wzajemności, które sa istotne w dobrym społeczeństwie ${ }^{16}$.

Oczywiście obecność obydwu logik, o których tu mówimy, oznacza, że interakcji społecznych nie da się sprowadzić tak po prostu albo tylko do „łożenia jednych na drugich", albo wyłącznie rozrachunków na zasadach ekwiwalentności. Zapewne wybranie zaledwie jednej z tych ścieżek funkcjonowania może się wydawać prostym wyjściem, lecz jest de facto pułapką. Pomimo to wydaje się, że w historii nie brakuje przykładów realizacji ładu społecznego w taki sposób. O ile przypadki utopijnego dążenia do uczynienia wszystkiego darmowym są ewidentnie nieracjonalne i nieskuteczne, o tyle złudzenie, że ład społeczny można oprzeć wyłącznie na logice kontraktu, znajduje kolejnych zwolenników. W tym wariancie szczególnie atrakcyjnie jawi się zapewne argument, według którego względnie nieskomplikowany mechanizm rynkowy - jako wiodący przykład logiki kontraktu - jest pewnym i najłatwiejszym sposobem na rozwiązywanie problemów w obrębie społeczeństwa. W tym kontekście jednak warto pamiętać o tym, na co zwraca uwagę Rocco Buttiglione, który pisze, że (...) kontrakt (...) możliwy jest jedynie $w$ sytuacji, gdy istnieje relatywna równowaga sit ${ }^{17}$. W konsekwencji więc należy zauważyć, że w sytuacji nierównowagi niezbędny jest najpierw dar, dzięki które-

\footnotetext{
${ }^{14}$ Ch. Delsol, op. cit., s. 157.

${ }^{15}$ Cf. np. R.N. Bellah, R. Madsen, W.M. Sullivan, A. Swidler, S.M. Tipton, Habits of the Heart: Individualism and Commitment in American Life, University of California Press, Berkeley-Los Angeles-London 1996, s. XI.

${ }^{16}$ L. Bruni, Reciprocity, Altruism and the Civil Society, Routledge, New York 2008, s. X.

${ }^{17}$ R. Buttiglione, Etyka wobec historii, Towarzystwo Naukowe Katolickiego Uniwersytetu Lubelskiego, Lublin 2005, s. 349.
} 
mu możliwe staje się wprowadzenie logiki kontraktu. W taki też sposób można rozumieć stwierdzenie George'a Gildera, według którego kapitalizm zaczyna się od dawania ${ }^{18}$. Widać to bardzo wyraźnie w procesie rozwoju człowieka, który zanim stanie się w maksymalnym stopniu dojrzałym i samodzielnym członkiem społeczności, zdolnym podejmować rozmaite role, w tym np. zawodowe, musi uzyskać wsparcie m.in. w postaci zapewnienia środków niezbędnych do życia i wzrostu w sensie biologicznym oraz poprzez wyposażenie w niezbędne kompetencje i umiejętności w procesie socjalizacji.

Powyżej przedstawione zagadnienia ukazują więc, dlaczego ekonomia nie wystarczy, by wyjaśnić funkcjonowanie społeczeństwa - nawet tzw. przemysłowego czy konsumpcyjnego, w którym wymiar gospodarczy wydaje się odgrywać zasadniczą rolę. Jest tak, gdyż nie jest ona w stanie dostarczyć adekwatnej antropologii, która byłaby w stanie uchwycić pełnię doświadczenia ludzkiego. W tym też kontekście problem tu podejmowany można sprowadzić do nieobecności w perspektywie ekonomicznej relacji niesymetrycznych, które należy uznać za nie mniej istotne dla społeczeństwa, a pod wieloma względami nawet za ważniejsze.

Powracając do sposobu postrzegania człowieka przez dominujący nurt teoretyczny w ekonomii, warto przybliżyć, jak jest on tam widziany. Cechą, która jawi się bardzo wyraźnie - co należy oczywiście wiązać z jego „modelową naturą” - jest jego abstrakcyjny, w jakimś sensie ahumanistyczny charakter. Przejawia się to po pierwsze w jego aseksualności, co oznacza, że tak istotny wymiar, jakim jest płciowość, pozostaje zignorowany, a wraz z nim różne doniosłe zadania i role społeczne, do których zaliczyć można chociażby rodzicielstwo. Wraz z tym znikają zasadnicze relacje i współzależności międzypokoleniowe, do których przy okazji podejmowania kwestii starości nie sposób się nie odwołać. Wynika z tego więc swoista pozaczasowość człowieka ekonomicznego - nie należy on do żadnego pokolenia, nie starzeje się, nie jest zaangażowany w żadne relacje międzyludzkie, nawet tak podstawowe, jak bycie dzieckiem swych rodziców. Jego ahumanistyczny charakter oznacza także, że nie można przypisać mu właściwie żadnej zmienności, co w konsekwencji prowadzi do wniosku, iż nie jest on podatny na upływ czasu, z czym wiąże się przecież nieuchronność określonych procesów i zmian, które dotyczą w sposób tak wyraźny właśnie okresu starości.

Spróbujemy ukazać te paradoksy, zestawiając relacje rodzinne i rynkowe jako sfery ukazujące odmienność dwóch logik, o których była mowa, i związanych z nimi sposobów odnoszenia się do drugiego człowieka. Pokazuje to Tabela $1^{19}$.

Wychodząc od powyższego zestawienia, warto postawić na pozór banalne pytanie o to, czy człowiek ekonomiczny, stworzony przede wszystkim dla relacji rynkowych, jest w stanie dać sobie sam radę na starość. Wydaje się, że oczywiście nie poradzi sobie w pojedynkę.

\footnotetext{
${ }^{18}$ G. Gilder, Wealth and Poverty, ICS Press, San Francisco 1993, s. 21.

${ }^{19}$ Ważne jest przy tym, aby pamiętać, że rynek nie jest tu traktowany jako synonim gospodarki, lecz że ta ostatnia stanowi sferę obszerniejszą.
} 
Tabela 1. Relacje rodzinne a relacje rynkowe

\begin{tabular}{|l|c|c|}
\hline Kategoria & Rodzina & Rynek \\
\hline dominujący charakter relacji & osobowy & rzeczowy \\
\hline horyzont czasowy relacji & relacje długofalowe & relacje krótkotrwałe \\
\hline stosunek stron relacji & asymetryczność & symetryczność \\
\hline gratyfikacja & $\begin{array}{c}\text { odłożona w czasie } \\
\text { lub rezygnacja z niej }\end{array}$ & $\begin{array}{c}\text { natychmiastowa/ } \\
\text { rzadziej: odłożona w czasie }\end{array}$ \\
\hline dominująca logika & daru & kontraktu \\
\hline perspektywa docelowa & osobowa & indywidualistyczna \\
\hline
\end{tabular}

Źródło: opracowanie własne.

Pomimo że widać to tak wyraźnie, nadal nie w pełni jest to uświadomione. Nawet jeśli obserwujemy w ekonomii nie tylko dyskusje i postulaty zmian, ale konkretne propozycje alternatywnego myślenia o gospodarującym człowieku w społeczeństwie, to trzeba zauważyć, że wiele faktycznych rozstrzygnięć administracyjno-prawnych dotyczących gospodarki odzwierciedla ten sposób myślenia, w którym to samotna jednostka w stylu Robinsona Crusoe jest głównym bohaterem działań. Problem jednak polega na tym, że dziś - w obliczu przemian demograficznych - wkracza on coraz wyraźniej w fazę starości, a przez to coraz większej wagi nabiera to właśnie pytanie, czy tak jak sam miał sobie dawać radę wcześniej, tak poradzi sobie teraz, i czy takie oczekiwanie jest realistyczne.

\section{Kulturowy kontekst a status starości}

Wobec powyższych analiz dotyczących wizji podmiotu działań i procesów społeczno-gospodarczych, jakim jest człowiek, warto postawić pytanie o to, dlaczego taki model antropologiczny zdominował myślenie, i to nie tylko ekonomiczne. Być może okazałby się on w jakimś stopniu przydatny, gdyby był traktowany wyłącznie jako model. Być może stało się tak, gdyż zakładano, że - po pierwsze - zawsze będzie on stosowany ze świadomością tego, iż jest tylko redukcją antropologiczną, a po drugie, że tak nieadekwatne uproszczenie nie będzie miało poważniejszych konsekwencji ideologicznych ${ }^{20}$.

Aby odpowiedzieć na powyższe kwestie, wydaje się niezbędne - i w znacznej mierze zostało to już dokonane - przyjrzenie się roli, jaką odgrywa ekonomia jako teoria starająca się tłumaczyć ludzkie działania przede wszystkim w domenie gospodarczej, a także - od jakiegoś czasu - w innych sferach, do których wkracza ze swymi metodami (ku wyraźnemu niezadowoleniu niektórych) ${ }^{21}$. By jednak w pełni uchwycić znaczenie teorii ekonomicznych, należy wyjść od znacznie szerszej perspektywy, jaką stanowi kultura. Rozumieć ją tu będziemy jako niema-

\footnotetext{
${ }^{20}$ Cf. S. Nowak, Metodologia badań społecznych, Wydawnictwo Naukowe PWN, Warszawa 2007, s. $28-29$.

${ }^{21}$ Cf. A. Lompart, Imperializm ekonomiczny - czy zagraża socjologii? [w:] Kulturowe aspekty transformacji ekonomicznej, red. J. Kochanowicz, S. Mandes, M. Marody, Instytut Spraw Publicznych, Warszawa 2007.
} 
terialną sferę, na którą składają się symbole, wartości i ideały ${ }^{22}$. Idąc za Samuelem P. Huntingtonem, można więc stwierdzić, że (...) definiujemy kulturę $w$ kategoriach czysto przedmiotowych jako wartości, postawy, przekonania, opinie oraz leżace u ich podstaw przeświadczenia powszechne wśród członków danej społeczności $i^{23}$.

Przyjęcie ram kulturowych okazuje się niezbędne, gdyż analizowana wcześniej ekonomia nie jest dyscypliną autonomiczną w sensie bycia w pełni niezależną od aktualnie dominujących rozstrzygnięć, które dokonują się właśnie na poziomie kultury. Dlatego też warto przywołać fragment analizy Davida Throsby'ego, który stwierdza:

Formalna precyzja nowoczesnej ekonomii, z jej abstrakcyjnymi teoriami, analiza matematyczna oraz wiara $w$ bezstronność naukowych metod weryfikacji hipotez na temat zachowania systemów gospodarczych, może sugerować, że ekonomia jest dziedzina pozbawiona kontekstu kulturowego, funkcjonujaca w świecie wolnym od wszelkich kulturowych uwarunkowań. A jednak, jako przedsięwzięcie intelektualne, nie jest ona niezależna od kultury, podobnie jak - zdaniem radykalnych krytyków wspótczesnej ekonomii - nie może być wolna od wartościowania ${ }^{24}$.

Skoncentruję się więc na kulturze po pierwsze dlatego, że poszczególne teorie, w tym ekonomiczne, odzwierciedlają w swych założeniach rozstrzygnięcia dokonane wcześniej na poziomie kultury, a po drugie, gdyż referując problem antropologii człowieka ekonomicznego w jakiejś mierze ukazaliśmy aktualnie dominujący w kulturze, a znajdujący odbicie w ekonomii sposób widzenia rzeczywistości.

Wychodzę więc z założenia, że analizowane tu problemy - ze szczególnym podkreśleniem problemu starości - mają źródła w podłożu kulturowym, które w ostatnich dziesięcioleciach uległo istotnym zmianom. W interesującym nas kontekście szczególnie ważne są więc wątki, które dotyczą kwestii tożsamości w odniesieniu do wieku i relacji międzypokoleniowych.

Obserwując aktualne realia społeczno-kulturowe, można odnieść wrażenie, które Manuel Castells opisał jako społeczną arytmię. Stanowi ona - szczególnie w zestawieniu z przeszłością - zjawisko, które zmusza do namysłu i poszukiwania adekwatnych wzorów działania. Przywołany autor stwierdza:

Obecnie organizacyjne, technologiczne i kulturowe wydarzenia, charakterystyczne dla nowego, wytaniającego się spoteczeństwa, zdecydowanie podważaja ten uporząkowany cykl życia, bez zastępowania go jakąkolwiek alternatywna sekwencją. Proponuje hipotezę, że społeczeństwo sieciowe charakteryzuje załamanie rytmów, zarówno biologicznych, jak i społecznych, powiąanych z pojęciem cyklu życia 25 .

\footnotetext{
${ }^{22}$ Cf. K. Krzysztofek, Cywilizacja: dwie optyki, Instytut Kultury, Warszawa 1991, s. 17.

${ }^{23}$ S.P. Huntington, Z kultura trzeba się liczyć [w:], Kultura ma znaczenie, red. L.E. Harrison, S.P. Huntington, tłum. S. Dymczyk, Zysk i S-ka Wydawnictwo, Poznań 2003, s. 14.

${ }^{24}$ D. Throsby, Ekonomia i kultura, tłum. O. Siara, Narodowe Centrum Kultury, Warszawa 2010, s. 22.

${ }^{25}$ M. Castells, Społeczeństwo sieci, tłum. M. Marody, K. Pawluś, J. Stawiński, S. Szymański, Wydawnictwo Naukowe PWN, Warszawa 2007, s. 444. Cf. P.L. Berger, T. Luckmann, Społeczne tworzenie rzeczywistości, tłum. J. Niżnik, Wydawnictwo Naukowe PWN, Warszawa 2010, s. 77-79.
} 
Kwestią podjętą przez Castellsa, szczególnie ważną dla podejmowanych tu rozważań, jest owo załamanie rytmów, które dotyczy zarówno indywidualnego kontekstu życia pojedynczego człowieka, jak też przekłada się na jego relacje międzyosobowe, także w perspektywie międzypokoleniowej. Oznacza ono, że tradycyjny i naturalny, bo wynikający z obiektywnych uwarunkowań biologicznych, cykl życia staje się w coraz większym stopniu kwestią, która poddawać ma się subiektywnemu kształtowaniu. Sprzyjają temu zapewne rozmaite osiągnięcia naukowo-techniczne, które, choć mogą dawać złudzenie opanowania nieuchronnych procesów fizjologicznych czy nadzieję ich spowolnienia, nie są w stanie ich zatrzymać czy odwrócić.

Jeśli chodzi o kierunek tych dążeń, to oczywiście ich pożądanym efektem jest przedłużenie, a może nawet zachowanie młodości, co w jakimś sensie odwołuje się do odwiecznych pragnień człowieka dotyczących nieśmiertelności i doskonałości. Szczególną cechą naszej epoki jest jednak to, że jak nigdy wcześniej człowiek dysponuje szeroką paletą możliwości, by móc podejmować próby urzeczywistniania takich aspiracji.

Żyjemy więc w epoce, którą zdaniem Roberta J. Samuelsona cechuje agelessness, co thumaczyć można jako abstrahowanie od wieku czy jego ignorowanie. Autor ten, cytowany przez Benjamina R. Barbera w książce Skonsumowani, stwierdza:

\begin{abstract}
Żyjemy w epoce, w której ludzie coraz mniej chca się zachowywać zgodnie ze swoim wiekiem. Młodzi (albo wielu z nich) pragna być starsi, starsi (albo wielu $z$ nich) pragna być młodsi. Zniszczyliśmy stopniowo tradycyjne etapy cyklu życia, skracając dzieciństwo, po którym nastapiło kilka blizej nieokreślonych stadiów przejściowych. Lata młodzieńcze (...) zaczynaja się przed okresem dojrzewania $i$ dla niektórych trwaja do końca życia (...) Wypieranie się własnego wieku jest zjawiskiem powszechnym ${ }^{26}$.
\end{abstract}

B.R. Barber, analizując tę kwestię, przywołuje kategorie infantylizacji i adultyzacji, ukazujące wprost konsekwencje zachwiania cyklu życia związanego ze społeczną arytmią, o której wcześniej była mowa. Pod tymi terminami kryje się $\mathrm{z}$ jednej strony tendencja do traktowania dorosłych jak dzieci, a z drugiej podchodzenia do dzieci tak, jakby były już samodzielne i dojrzałe. Obszarem, na którym jest to szczególnie widoczne, jest rynek, gdzie produkty i usługi niegdyś zarezerwowane dla określonych kategorii wiekowych są adresowane do odbiorców, którzy wcześniej nie znajdowali się w grupie docelowej. Od strony ekonomicznej ma to oczywiście prowadzić do poszerzenia grupy nabywców, a w konsekwencji do powiększania rynku i wzrostu zysków. Od strony kulturowej prowadzi to jednak do homogenizacji i zacierania istotnych pod względem funkcjonowania ładu społecznego rozróżnień. W rezultacie, obiektywne - i na swój sposób uniwersalne - różnice pokoleniowe i związane z nimi role i powinności ustępują miejsca kształtowanej $\mathrm{w}$ sposób zindywidualizowany i czysto subiektywny tożsamości

\footnotetext{
${ }^{26}$ R.J. Samuelson, Adventures in Agelessness, „Newsweek” 2003, 3 listopada, cyt. za: B.R. Barber, Skonsumowani. Jak rynek psuje dzieci, infantylizuje doroslych i polyka obywateli, Warszawskie Wydawnictwo Literackie Muza SA, Warszawa 2009, s. 12-13.
} 
jednostkowej. Wskutek tego wiek, który niegdyś w większym stopniu wyznaczał przynależność do określonych grup i specyfikę podejmowanych ról społecznych, w aktualnym kontekście kulturowym bywa częściej postrzegany jako element, który można traktować w sposób dowolny, w zależności od subiektywnych preferencji.

Jest to jedna z konsekwencji silnego akcentowania we współczesnej kulturze indywidualizmu, który na plan dalszy usuwa zapośredniczenie osoby ludzkiej w grupach pierwotnych (takich jak rodzina) i innych wspólnotach, ze społeczeństwem włącznie. To absolutyzowanie wymiaru jednostkowego stanowi jednakże obietnicę bez pokrycia i paradoksalnie, jak stwierdza Ulrich Beck, jednostka (...) traci znaczenie i równocześnie stawiana jest na pozornym piedestale wspóttwórcy świata ${ }^{27}$. Oznacza to więc swoisty kryzys tego, co wspólne, a więc świata życia i związanej z nim wspólnoty wartości i ideałów, które stanowią przecież treść kultury. W konsekwencji miejsce wspólnie odbieranej, tworzonej i przeżywanej rzeczywistości zajmuje mnogość równoległych światów, których status pod względem realności może być kwestią dyskusyjną. Pośrednim potwierdzeniem tego może być popularność mass mediów, szczególnie programów, które oferują wstęp do świata nierzeczywistego. Zwracają na to uwagę Alvin i Heidi Tofflerowie, którzy piszą, że

(...) miliony ludzi ucieka $w$ zachtanne ogladanie telewizji, gdzie programy emitowane w konwencji reality show udaja rzeczywistość. Tysiace ludzi umawia się, tworzac flash mob i zgromadziwszy się tlumnie $w$ jednym miejscu wszczyna wielka bitwę na poduszki. A jeszcze gdzie indziej uczestnicy gier online płaca tysiace jak najbardziej autentycznych dolarów za wirtualne miecze, za pomoca których, jako wirtualni wojownicy, moga zdobywać wirtualne zamki czy dziewice. Nierealność rozprzestrzenia się $^{28}$.

Mamy więc do czynienia z kulturą, która na różne sposoby próbuje dystansować się od rzeczywistości, co z kolei pozwala stwierdzić, że mamy do czynienia z powszechnym i silnym kultywowaniem raczej młodości, gdyż to jej bliższe są beztroska, zabawa i nietraktowanie poważnie obiektywnych warunków i ograniczeń. A właśnie w tym wyraźnie znajduje upodobanie współczesna kultura.

Bohaterem tak scharakteryzowanej teraźniejszości jest zatem raczej człowiek młody, zdrowy, piękny, inteligentny, bogaty, a nie stary, schorowany, ubogi i słaby. To z kolei daje podstawy, by określić aktualnie dominujący sposób postrzegania i wartościowania jako kulturę silnych, przez którą - w wymiarze etycznym - przebija społeczny darwinizm ${ }^{29}$. Problem ten interesująco przedstawia w swej książce Wojna przeciw słabym Edwin Black, pokazując, jak wydarzenia $\mathrm{XX}$ wieku, ze szczególnym uwzględnieniem ludobójstwa II wojny światowej, ideowo korzeniami sięgają dziewiętnastowiecznej eugeniki, i w znacznej mierze

\footnotetext{
${ }^{27}$ U. Beck, Społeczeństwo ryzyka. W drodze do innej nowoczesności, tłum. S. Cieśla, Wydawnictwo Naukowe Scholar, Warszawa 2002, s. 205.

${ }^{28}$ A. Toffler, H. Toffler, Rewolucyjne bogactwo, Wydawnictwo Kurpisz SA, Przeźmierowo 2007, s. 14.

${ }^{29}$ Cf. E. Black, Wojna przeciw słabym. Eugenika i amerykańska kampania na rzecz stworzenia rasy panów, tłum. H. Jankowska, Warszawskie Wydawnictwo Literackie MUZA SA, Warszawa 2004, s. 47.
} 
podlegają kontynuacji w XXI wieku, gdy wartość życia ludzkiego staje się przedmiotem albo czysto indywidualnej decyzji, albo kwestią, o której przesądzać ma większość. Problem ten ukazuje Black, gdy pisze:

Planiści spoleczni uznali, że w walce o byt $w$ bezwzględnym świecie wielu ludzi jest nie tylko mniej wartościowych, lecz $w$ dążeniu do postępu zostali skazani na eliminację. Utrzymywanie stabych i ubogich jest $z$ zasady czymś sprzecznym z naturą ${ }^{30}$.

Współczesna kultura właściwie oznacza regres, bo cofa człowieka do poziomu przyrody, w której zasadniczymi regulatorami są właśnie siła i zdolność przystosowania się do panujących warunków. W kontekście statusu podmiotu w świecie czyni go ona osobnikiem, przekreślając zarazem jego bycie osobą.

Dobrą ilustracją tego problemu jest sytuacja dziecka w ogóle, a nienarodzonego w sposób szczególny, oraz człowieka starszego. Jak tłumaczy to Buttiglione, w kontekście przywoływanych wcześniej logik:

spotykamy tu oczywisty model podmiotu, który jest całkowicie pozbawiony sity i dlatego jest wykluczony z kontraktu. Kwestia legalizacji aborcji-niezależnie od swej obiektywnej powagi moralnej - jest także kamieniem probierczym antropologii i zarazem samoświadomości narodu, jest bowiem kamieniem probierczym jakości pojęcia sprawiedliwości, na którym naród zamierza oprzeć swe istnienie. (...) Analogiczny jest przypadek człowieka starszego. Człowiek stary traci stopniowo siłe, tracac tym samym - wedle koncepcji sprawiedliwości konwencjonalnej - również prawa. W końcowej fazie swego życia pozbawiony jest już całkowicie sity, jak i praw. Również czlowiek chory i upośledzony znajduje się w podobnej sytuacji ${ }^{31}$.

Powyższe spostrzeżenia dają więc podstawy, by stwierdzić, że aktualne rozstrzygnięcia na poziomie kultury wpływają na sposób postrzegania starości oraz na status człowieka starego w społeczeństwie.

\section{Podsumowanie. Jaka przyszłość dla starzejącego się spoleczeństwa?}

Konkludując, można stwierdzić, że o losach i przyszłości starzejących się społeczeństw będą decydowały w większym stopniu akceptowane założenia kulturowe, w tym m.in. antropologiczne, etyczne oraz te zawarte w koncepcjach ekonomicznych, niż aktualnie posiadane zasoby materialne ${ }^{32}$. Oznacza to, że teoria ma ogromne znaczenie. Okazuje się to szczególnie ważne w kontekście bardzo rozpowszechnionego i popularnego współcześnie pragmatycznego stylu życia.

\footnotetext{
${ }^{30}$ Ibidem.

${ }^{31}$ R. Buttiglione, op. cit., s. 349.

${ }^{32}$ Przykładem tego może być kwestia skuteczności pomocy finansowej państwa w podnoszeniu dzietności kobiet w różnych krajach.
} 
W znacznej mierze w taki właśnie sposób zdają się funkcjonować współczesne reżimy opiekuńcze, które cechuje - pomimo ich oczywistej różnorodności - przekonanie, że zapewnienie niezbędnego minimum egzystencjalnego stanowi klucz do zadowolenia społecznego i rozwoju. Niestety rzeczywistość pokazuje co innego. W kontekście zaś podejmowanego tu tematu państwa opiekuńcze wydają się zbyt scentralizowane, by adekwatnie podchodzić do problemu starości, która - za sprawą swej różnorodności i nieprzewidywalności - jest trudnym zagadnieniem dla zarządzania podejmowanego w makrostrukturach kraju, które trudniej radzą sobie w sytuacjach niestandardowych i nierutynowych.

Innym problemem państwa typu welfare state jest jego wpływ na status pracy opiekuńczej - niezbędnej zarówno w stosunku do dzieci, jak i osób starszych - która ulega deprecjacji. Dzieje się tak dlatego, że państwo, przejmując niejako „na siebie” ${ }^{33}$ zapewnienie opieki i zabezpieczenia socjalnego, daje fałszywy sygnał, iż naturalne zależności pomiędzy funkcjonowaniem rodziny, realizującej takie funkcje, jak chociażby funkcja prokreacyjna, socjalizacyjna czy opiekuńcza, a generowaniem środków dla systemu zabezpieczenia społecznego tracą moc. Wskutek tego w ogólnej świadomości pojawia się przekonanie, że podejmowanie ról i obowiązków rodzinnych, w szczególności tych związanych z pracą wychowawczą i opiekuńczą, nie jest niezbędne z punktu widzenia funkcjonowania państwa i społeczeństwa. W ten sposób oraz przez fakt, że praca opiekuńcza i wychowawcza jest wymagająca $\mathrm{i}$ trudna, i niestety często niewynagradzana, kształtuje się jej niska pozycja kulturowa. To z kolei jest odbierane jako ważny sygnał przez kolejne pokolenia wkraczające w dorosłość i w konsekwencji prowadzi do tego, że ten rodzaj pracy jest coraz rzadziej wybierany i podejmowany, co w sposób realny przekłada się na kryzys demograficzny i gospodarczy wielu państw opiekuńczych.

Mamy więc do czynienia z sytuacją, gdy dominujący - szczególnie w obrębie cywilizacji zachodniej - kształt kultury z jednej strony silnie akcentuje indywidualizm i jednostkową autonomię, a z drugiej utrwala bierność obywateli zakładających, że państwo zaopiekuje się nimi w każdych okolicznościach, a więc także w okresie ich starości. Pod względem kondycji i konkurencyjności okazuje się dziś coraz wyraźniej, że Zachód zaczyna ustępować miejsca innym cywilizacjom. Istotną konsekwencją takiego stanu jest przywoływane już wcześniej zjawisko starzenia się społeczeństwa, które związane jest $\mathrm{z}$ analizowanymi tu procesami. Podejmowane są oczywiście próby podtrzymywania ładu społeczno-gospodarczego, ale są one nastawione raczej na krótką perspektywę czasową.

W takim kontekście realizowany jest, w niektórych krajach już od lat, scenariusz bazujący na imigracji, dzięki której uzupełniane są braki w populacji, co z kolei umożliwić ma podtrzymanie zasadniczych „funkcji życiowych” danego społeczeństwa. W takim jednak przypadku skutkiem nieuchronnym staje się mniej lub bardziej zasadnicza zmiana kulturowa, która coraz wyraźniej potwierdza jało-

\footnotetext{
${ }^{33}$ Użyty cudzysłów oznacza, że de facto państwo nie ma „swoich” pieniędzy, lecz że swe przedsięwzięcia finansuje przede wszystkim ze środków wypracowanych przez obywateli, którzy w znacznym stopniu stali się dorosłymi i dojrzałymi członkami społeczeństwa dzięki nieodpłatnej pracy opiekuńczo-wychowawczej podejmowanej w rodzinach.
} 
wość kultury nierespektującej tego, że dla dobrze funkcjonującej umowy międzypokoleniowej potrzebna jest równowaga pomiędzy generacjami, dzięki której społeczeństwo rozwija się i optymalnie oraz adekwatnie angażuje i wykorzystuje potencjał poszczególnych pokoleń.

Jakąś alternatywą, która bywa traktowana być może jako nieuchronność, a po części jako próba dostosowania się do aktualnych trendów demograficznych, jest tzw. siwiejąca gospodarka (greying economy). Stanowi ona jednak raczej pomysł na krótkookresowe dostosowanie się do trendów demograficznych, aniżeli kompleksowe i adekwatne rozwiązanie problemu, który staje się coraz bardziej wyraźny. Oczywiście można akcentować konieczność zapewnienia podaży produktów i usług dla osób starszych, ale od strony poważnej polityki społecznej należy stawiać pytanie o to, co należy robić w kontekście całości społeczeństwa, które po prostu zaczyna wymierać.

Należy się wobec tego zastanawiać, czy chęć urzeczywistnienia tzw. greying society nie będzie - bez gruntownego przemyślenia wcześniej opisywanych rozstrzygnięć kulturowych - raczej próbą uczynienia ludzi starych tak silnymi i sprawnymi, jak tylko się da, zamiast uważnego rozpoznania i zaakceptowania specyfiki i znaczenia starości dla ładu społecznego. Oczekiwanie przecież, że w nowym kontekście wszyscy ludzie starzy będą w stanie dostosować się do nowych wyzwań, takich jak np. wydłużenie okresu aktywności zawodowej, jest dalekie od realizmu.

Wydaje się więc uzasadnione, że „siwiejąca gospodarka” nie jest właściwym rozwiązaniem, choć $\mathrm{z}$ racji starzenia się społeczeństwa w jakimś zakresie i w perspektywie krótkoterminowej zapewne się pojawi, by odpowiedzieć na wzrastający popyt na określone produkty i usługi ze strony osób starszych. Sama jednak koncepcja takiego systemu nie jest w stanie zaoferować adekwatnego wyjścia, gdyż niezbędna jest odpowiednia filozofia społeczna, wyrastająca z kultury, która będzie respektowała obiektywne cechy i atrybuty ludzkiego życia w wymiarze osobowym, łączącym i ukazującym jako niezbędne i wzajemnie komplementarne takie wymiary egzystencji człowieka, jak indywidualny i wspólnotowy. W takim kontekście na uwagę zasługuje spostrzeżenie ekonomistki Jennifer Roback Morse, która pisze:

Społeczeństwa czynia lepiej, gdy raczej stawiaja czoło faktom, niż je ignorują. W szczególności filozofie polityczne i towarzyszace im filozofie społeczne musza odwoływać się do ograniczeń ludzkiej sity. Wszyscy jesteśmy zupetnie niesamodzielni w okresie niemowlęctwa, i nawet dorośli u szczytu swych możliwości sa dalecy od bycia wszechmocnymi. Jeśli filozofie i spoleczeństwa zbudowane $w$ oparciu o nie ignoruja którąkolwiek z tych prawd dotyczacych ludzkiej bezsilności, będzie to miało negatywne konsekwencje ${ }^{34}$.

Poruszone tu problemy z pewnością zasługują na pogłębienie i poszerzenie, tym bardziej że podjęta analiza w jakimś stopniu ujawniła ich złożoność i wielowymiarowość. Wydaje się, że ich podjęcie można wręcz uznać za niezbędne nie

\footnotetext{
${ }^{34}$ J. Roback Morse, Love \& Economics..., s. 27.
} 
tylko po to, by harmonizować aktualne napięcia i związane z nimi wyzwania, ale, co równie, a może nawet bardziej istotne, by poszukiwać takich rozstrzygnięć kulturowych, które będą sprzyjały spójnemu rozwojowi społeczeństw. W sposób zasadny można stwierdzić, że będzie on tylko wtedy możliwy, gdy respektowane będą m.in. te fundamentalne reguły rządzące ludzkim życiem, które - w przypadku tematu tu podjętego - ukazują obiektywną wagę i sens każdej fazy ludzkiego życia zarówno w wymiarze indywidualnym, jak i międzypokoleniowym w skali społeczeństwa.

\section{Bibliografia}

Barber B.R., Skonsumowani. Jak rynek psuje dzieci, infantylizuje dorostych i potyka obywateli, Warszawskie Wydawnictwo Literackie Muza SA, Warszawa 2009.

Beck U., Społeczeństwo ryzyka. $W$ drodze do innej nowoczesności, Wydawnictwo Naukowe Scholar, Warszawa 2002.

Bellah R.N., R. Madsen, W.M. Sullivan, A. Swidler, S.M. Tipton, Habits of the Heart: Individualism and Commitment in American Life, University of California Press, Berkeley-Los Angeles-London 1996.

Berger P.L., T. Luckmann, Społeczne tworzenie rzeczywistości, Wydawnictwo Naukowe PWN, Warszawa 2010.

Black E., Wojna przeciw słabym. Eugenika i amerykańska kampania na rzecz stworzenia rasy panów, Warszawskie Wydawnictwo Literackie MUZA SA, Warszawa 2004.

Bruni L., Reciprocity, Altruism and the Civil Society, Routledge, New York 2008.

Buttiglione R., Etyka wobec historii, Towarzystwo Naukowe Katolickiego Uniwersytetu Lubelskiego, Lublin 2005.

Castells M., Społeczeństwo sieci, Wydawnictwo Naukowe PWN, Warszawa 2007.

Delsol Ch., Esej o człowieku późnej nowoczesności, tłum. M. Kowalska, Znak, Kraków 2003.

Gilder G., Wealth and Poverty, ICS Press, San Francisco 1993.

Golinowska S., Społeczno-ekonomiczne konsekwencje starzenia się ludności [w:] Konsekwencje ekonomiczne i społeczne starzenia się społeczeństwa, red. J. Kleer, Komitet Prognoz „Polska 2000 plus” przy Prezydium PAN, Warszawa 2008.

Huntington S.P., Z kultura trzeba się liczyć [w:] Kultura ma znaczenie, red. L.E. Harrison, S.P. Huntington, Zysk i S-ka Wydawnictwo, Poznań 2003.

Jurek Ł., Ekonomia starzejącego się społeczeństwa, Difin, Warszawa 2012.

Knight F., The Ethics of Competition, New York 1951, cyt. za: A. Chmielecki, Rzeczy $i$ wartości. Humanistyczne podstawy edukacji ekonomicznej, Wydawnictwo Naukowe PWN, Warszawa 1999.

Krzysztofek K., Cywilizacja: dwie optyki, Instytut Kultury, Warszawa 1991.

Lompart A., Imperializm ekonomiczny - czy zagraża socjologii? [w:] Kulturowe aspekty transformacji ekonomicznej, red. J. Kochanowicz, S. Mandes, M. Marody, Instytut Spraw Publicznych, Warszawa 2007.

Morawski W., Socjologia ekonomiczna. Problemy. Teoria. Empiria, Wydawnictwo Naukowe PWN, Warszawa 2001. 
Nowak S., Metodologia badań spolecznych, Wydawnictwo Naukowe PWN, Warszawa 2007.

Roback Morse J., Love \& Economics: Why the Laissez-Faire Family Doesn't Work, Spence Publishing Company, Dallas 2001.

Samuelson R.J., Adventures in Agelessness, „Newsweek” 2003, 3 listopada.

Sobczyk J.R., Historia naturalna homo oeconomicus - od narodzin po cywilizacyjny kryzys wspótczesności [w:] Kultura a rynek, red. S. Partycki, Wydawnictwo KUL, Lublin 2008.

Stankiewicz W., Historia myśli ekonomicznej, Polskie Wydawnictwo Ekonomiczne, Warszawa 1998.

Szczepański J., Sprawy ludzkie, Czytelnik, Warszawa 1980.

Throsby D., Ekonomia i kultura, Narodowe Centrum Kultury, Warszawa 2010.

Toffler A., H. Toffler, Rewolucyjne bogactwo, Wydawnictwo Kurpisz SA, Przeźmierowo 2007.

Zaidi A., Well-being of Older People in Ageing Societies, Ashgate, Aldershot 2008. 